\title{
Particle packing of cement and silica fume in pastes using an analytical model
}

\section{Empacotamento de partículas de cimento e sílica ativa em pastas pelo uso de modelo analítico}

A. HERMANN a

enge.aline@hotmail.com

E. A. LANGARO elolangaro@hotmail.com

S. H. LOPES DA SILVA ${ }^{a}$ sarahhlds@gmail.com

N. S. KLEIN b

nayaraklein@ufpr.br

\begin{abstract}
When added to concrete in appropriate content, silica fume may provide an increase in the mechanical strength of the material due to its high pozzolanic reactivity. In addition to the chemical contribution, physical changes can also be observed in concretes with silica fume due to an improvement in the particle packing of the paste. This is a result of their small size spherical particles, which fill the voids between the larger cement grains. However, it is necessary to properly establish the cement replacement content by silica fume, because at high amounts, which exceed the volume of voids between the cement particles, silica fume can promote the loosening of these particles. Thus, instead of filling the voids and increasing the packing density, the addition of silica fume will increase the volume of voids, decreasing the solid concentration. Consequently, this will impair the properties of the concrete. The objective of this paper is to use a particle packing analytical model, the CPM (Compressible Packing Model), to verify the maximum packing density of cement and silica fume, which could be associated with the silica fume optimum content in pastes. The ideal content of silica fume in pastes, mortars and concretes is usually experimentally determined. However, a theoretical study to contrast experimental data may help understanding the behaviour of silica fume in mixes. Theoretical results show maximum amounts of silica fume in the order of 18 to $20 \%$ of the cement weight, which is high considering recommendations on literature of $15 \%$. Nevertheless, the packing model does not consider the effect of silica fume high specific surface on the agglomeration of particles or water demand. Hence, the packing density predicted by this model cannot be used as the single parameter in determining the optimum amount of silica fume in pastes.
\end{abstract}

Keywords: silica fume; packing of fine particles; wet packing; analytical model; CPM.

\section{Resumo}

Pela sua pozolanicidade e alta reatividade, a sílica ativa, quando adicionada ao concreto em porcentagens adequadas, pode proporcionar um aumento na resistência mecânica do material. Além da contribuição química, alterações físicas no concreto com sílica ativa também são observadas pela melhora no empacotamento de partículas na pasta, resultado de suas pequenas partículas esféricas que preenchem os vazios entre os grãos de cimento, de maior tamanho. Para tanto, é necessário prever o teor de substituição adequadamente, pois em teores muito elevados, que superem o volume de vazios entre as partículas de cimento, a sílica pode promover o afastamento destas partículas. Assim, ao invés de preencher os vazios e aumentar a densidade de empacotamento, a adição de sílica irá aumentar o volume de vazios, diminuindo a concentração de sólidos na pasta e, consequentemente, prejudicando as propriedades do concreto. Dessa forma, o objetivo deste trabalho é utilizar um modelo analítico de empacotamento de partículas, o CPM (do inglês Compressible Packing Model), para verificar a densidade de empacotamento máxima de pastas de cimento e sílica ativa. Esta poderia estar associada ao teor ótimo de sílica ativa em pastas. A porcentagem ideal de sílica ativa em pastas, argamassas e concretos é comumente determinada experimentalmente. Porém, um estudo teórico para contrastar os valores experimentais poderia auxiliar no entendimento do comportamento da sílica ativa em misturas. Os resultados teóricos apontam para quantidades máximas na ordem de 18 a $20 \%$ sobre a massa de cimento. Estes valores são elevados se considerada a recomendação máxima da literatura de $15 \%$. No entanto, o modelo de empacotamento não considera o efeito da elevada superfície específica da sílica ativa na aglomeração das partículas e na demanda de água, de modo que não se recomenda a utilização deste como parâmetro único para a determinação do teor ótimo de sílica ativa em pastas.

Palavras-chave: sílica ativa; empacotamento de partículas finas; empacotamento na condição úmida; modelo analítico; CPM. 


\section{Introduction}

The cementitious composites like concretes, mortars and pastes are made of granular materials of different shapes and sizes. An ideal combination between them, aiming maximum compactness, has a direct effect in the mechanical strength and the durability of the composites. The silica fume is one of the most commonly used mineral admixtures in concretes, especially in high-strength concrete (HSC). The HSC mixtures present high mechanical strength as well as reduced porosity and permeability, thereby increasing the durability of the material $[1,2,3]$.

The silica fume used as a mineral admixture can act in two ways. The first one is the chemical action by the pozzolanic reaction, where the silica fume reacts chemically with the calcium hydroxide, $\mathrm{Ca}(\mathrm{OH})_{2}$, resulting from cement hydration. This reaction produces an additional amount of calcium silicate hydrate (C-S-H), which increases the mechanical strength of the concrete. Moreover, as $\mathrm{C}-\mathrm{S}-\mathrm{H}$ contributes to reduce the volume of voids, it increases the resistance to the attack of the aggressive agents [4].

The second role played by the silica fume is the filler effect, this being a physical effect. Approximately $80 \%$ of the silica fume particles range in sizes between 0,1 to $1 \mu \mathrm{m}[5,6,7]$. Because of its fineness, the silica fume has the ability to fill the voids between the larger particles of cement [2, 7, 8], as shown in Figures 1(a) and (b). This contributes to the densification of both the cement paste and the interfacial transition zone, producing a denser microstructure, with a smaller voids ratio $[2,9,10,11]$

Usually, the silica fume is used in amounts ranging from 5 to $15 \%$ by cement weight $[3,12,13,14,15]$. In this range, the addition of silica fume can improve the workability of the mix because its particles fill the voids between the cement grains. Consequently, the water that once occupied these spaces is released to work in the fluidization of the mixture. However, when added in amounts exceeding $15 \%$, silica fume can increase the water consumption required to maintain the same level of consistency. This happens because the amount of water released is not enough to surround the fine particles, whose specific surface area is high. Therefore, the thickness of the excess water layer formed around each particle is reduced, which makes the mixtures drier $[16,17]$. Furthermore, when the volume of silica fume added exceeds the volume of voids between the cement grains, of larger size, the so-called loosening effect occurs and the larger particles are pushed away from each other by the smaller particles [18], as shown in Figure 1(c). This contributes to an increase in the volume of voids; therefore, the volume of water needed to fill this voids also increases.

\subsection{Objective}

The objective of this work is to use an analytical particle packing model, the CPM (Compressible Packing Model), proposed by De Larrard [18], in order to verify de maximum packing density of binary pastes of Portland cement and silica fume. This maximum packing density could be associated with the optimum content of silica fume in pastes. The results obtained from the theoretical model will be compared with experimental results.

\subsection{Justification}

The use of analytical packing models is justified because it allows mathematically contrasting the optimal amount of silica fume in concretes, between 5 and $15 \%$ by cement weight, which are usually determined experimentally. The CPM model was chosen because among the several existing models it is the most suitable one to work with fine materials [19].

\section{Analytical packing model: CPM}

The packing density of a mixture is defined as the volume of solids in a total unit volume $[18,19,20]$. Among the analytical particle packing models that determine the packing density of a granular assembly, the model proposed by De Larrard [18] is one of the most known and it is highly possible to apply it for fine materials

\section{Figure 1 - Physical effects of silica fume on (a) the cement particles: (b) filler effect and (c) loosening effect}

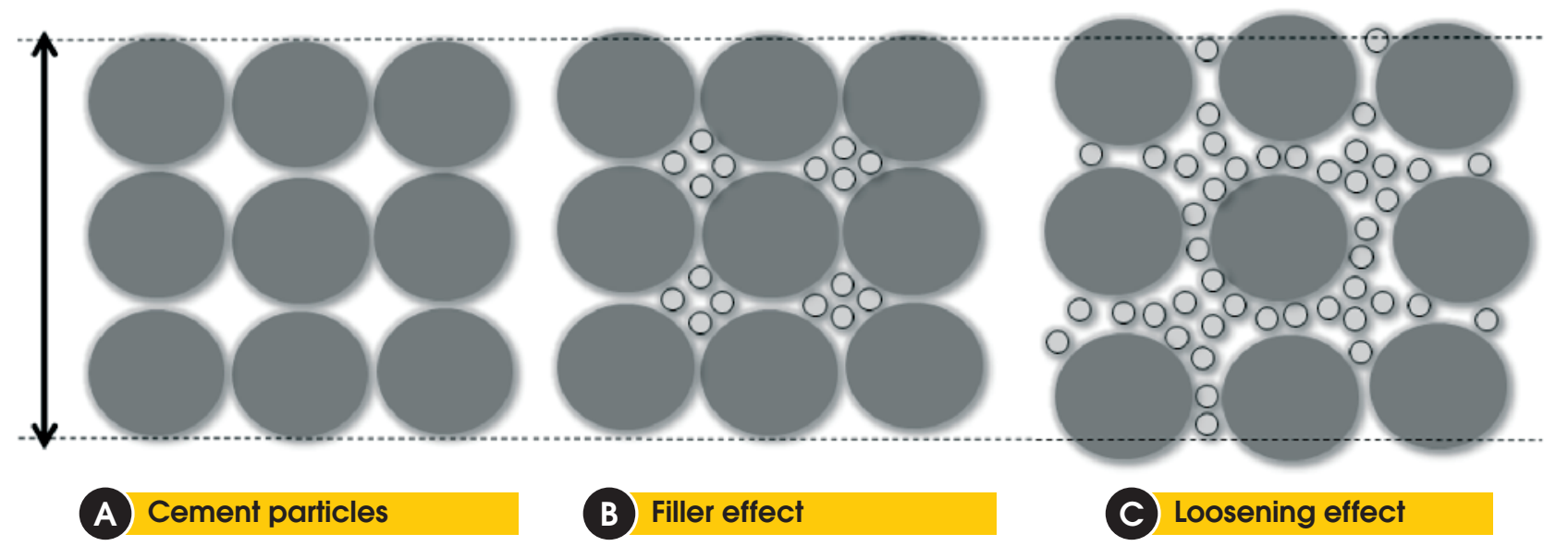


[19]. This model was developed for aggregates; therefore, it does not consider the water in the mixture nor the attractive forces between the fine particles. Thus, in order to apply the model for fine materials it is necessary to use a superplasticizer, so the agglomeration of the fine particles is minimised.

It is also important to note that the CPM model requires the packing density of each grain size class as input. Since the present study uses fine materials like the cement and the silica fume, it was decided to consider each of these materials as a separated grain size class. This is feasible because both these materials present different diameters, being the silica fume two orders of magnitude thinner than cement, as mentioned before [4].

The calculation of the virtual packing density of a group of particles is done according to equations 1 and 2 [18]. The virtual packing density is the maximum packing density achievable for a granular assembly, when its particles are placed one by one in order to occupy the maximum possible space.

$$
\gamma=\operatorname{Min}\left(\gamma_{i}\right)
$$

$$
\gamma_{i}=\frac{\beta_{i}}{1-\sum_{j=1}^{i-1}\left[1-\beta_{i}+b_{i j} \beta_{i}\left(1-\frac{1}{\beta_{j}}\right)\right] y_{j}-\sum_{j=i+1}^{n}\left[1-a_{i j} \frac{\beta_{i}}{\beta_{j}}\right] y_{j}}
$$

Where:

$\gamma$ : virtual packing density of a granular assembly;

$\gamma_{i}$ : virtual packing density of a granular assembly when the class $i$ is dominant;

$\beta_{i}$ : packing density of the class $i$;

$y_{i}$ : volume fraction of the class $i$.

The coefficients $a_{i j}$ and $b_{i j}$ represent the interactions considered by the model, the loosening effect and the wall effect, respectively. These coefficients are calculated according to equations 3 and 4 . Lastly, equation 5 shows the calculation of the actual packing density, where the compaction energy applied to the mixture is considered through the compaction index $\mathrm{K}$.

$a_{i j}=\sqrt{1-\left(1-\frac{d_{j}}{d_{i}}\right)^{1,02}}$

$$
b_{i j}=1-\left(1-\frac{d_{i}}{d_{j}}\right)^{1,50}
$$

$$
K=\sum_{i=1}^{n} K_{i}=\sum_{i=1}^{n} \frac{y_{i} / \beta_{i}}{1 / \varphi-1 / \gamma_{i}}
$$

Where:

$\mathrm{d}_{\mathrm{i}}$ : particle diameter of class $\mathrm{i}$;

$\mathrm{K}$ : compaction index;

$\varphi$ : actual packing density of the granular assembly.

\section{Determination of the packing density of the fine particles}

For the determination of the packing density of the cement and the silica fume an experimental wet packing method was used [21, 22]. The determination of the packing density of the fine particles through a dry packing method, without the presence of water, can result in some problems. This is true because the packing density experimentally determined is very sensitive to the applied compaction and to the effects of both the water and the chemical admixtures, which are not considered through the dry packing methods [6].

Fine particles are subjected to interparticle cohesive forces (Van der Waals forces) forming small agglomerates of particles. When the weight (the force of gravity) acting on a particle (which depends on both the particle mass and the acceleration of gravity, which is constant) is less than the attraction forces between particles, there will be agglomeration [23, 24]. Thus, it is more appropriate to use a wet packing method to determine the packing density of the fine particles, which are subjected to agglomeration due to high interaction between the particles. By using a wet packing method, it is possible to measure the influence of the water and to use the same chemical admixtures and compaction methods that will be used in the production of concretes. This would represent the actual conditions to which the component materials will be subjected during production.

The experimental method consists of producing pastes (fine material + water) with several water/binder ratios $(\mathrm{w} / \mathrm{b})$. After that, the mass of a known volume of the produced paste is determined using the container commonly used for determining the specific gravity of mortar. Through equations 6 to 8 it is possible to determine the voids ratio and the solid concentration of each mixture [21, 22]. This procedure was carried out for the cement and the silica fume, separately. The data obtained for each material were used as input parameter to the particle packing model, CPM [18], from which it was determined the ideal theoretical proportion of cement and silica fume needed for maximum packing density.

$$
V_{S}=\frac{M}{\rho_{w} u_{w}+\sum_{i=1}^{n} \rho_{i} R_{i}}
$$

$$
u=\frac{V-V_{S}}{V_{S}}
$$

$$
\varnothing=\frac{V_{S}}{V}
$$




\section{Figure 2 - Typical graph obtained when determining the packing density in the wet condition, adapted from $(21,22)$}

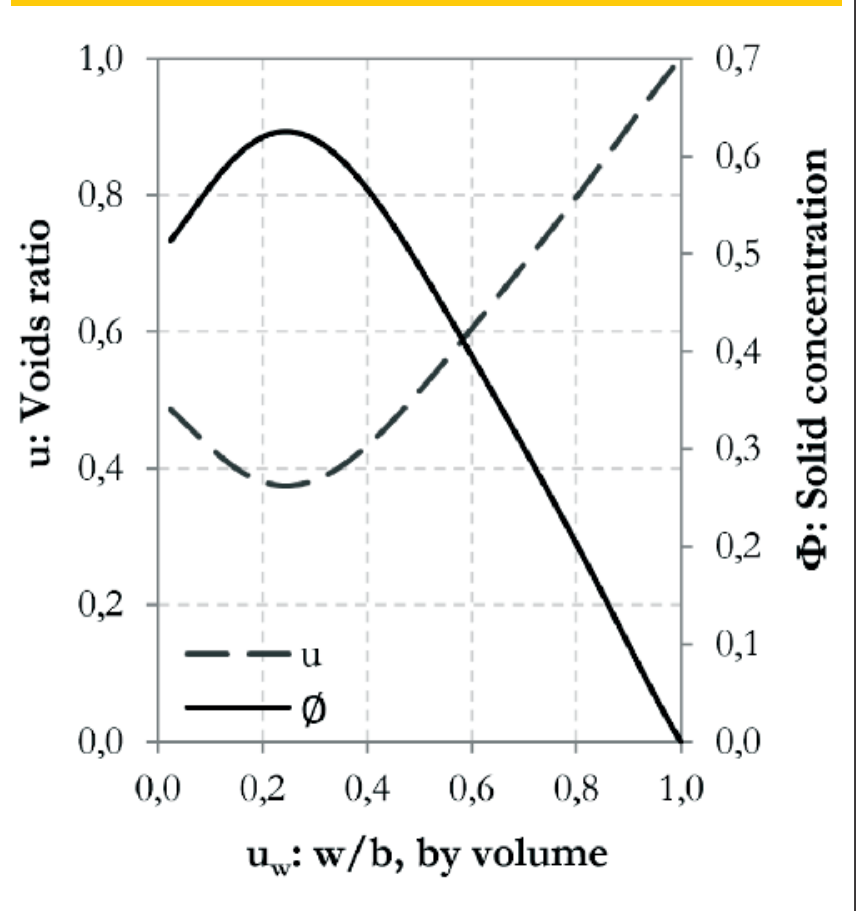

Where:

$\mathrm{V}_{\mathrm{s}}$ : volume of binders;

M: mass of paste in the mould;

$\mathrm{V}$ : volume of paste in the mould;

$\rho_{w}$ : density of water;

$\mathrm{u}_{\mathrm{w}}$ : water ratio, which is numerically equal to the $\mathrm{w} / \mathrm{b}$, by volume;

$\rho_{i}$ : solid density of the material $i$;

$\mathrm{R}_{\mathrm{i}}$ : volumetric ratio of the material $\mathrm{i}$;

$\mathrm{u}$ : voids ratio;

$\emptyset=$ solid concentration.

Figure 2 shows a typical graph obtained as a result of this experiment. It is observed that when the $w / b$ ratio is high, the voids ratio is also high, since the solid particles are separated from each other due to the fact they are surrounded by water. Consequently, the solid concentration is low. When the $\mathrm{w} / \mathrm{b}$ ratio decreases, the particles approach each other. Therefore, the voids ratio decreases and the solid concentration increases progressively. This occurs until a critical point is reached, where the voids ratio is minimal and the solid concentration is maximum. In this situation, the particles are only connected to each other by water bonds at the contact points between grains. From this point on, if the $w / b$ ratio is once again decreased, there will not be enough water in the mixture and the water bridges between the particles will be broken. Therefore, particles will move away from each other, decreasing the solid concentration and increasing the voids ratio $[6,23]$.

By analysing the curves shown in Figure 2, it is verified that the maximum solid concentration obtained can be associated with the particle packing density in the wet condition. Moreover, from this point of maximum solid concentration it can be determined the minimum amount of water necessary for the formation of a homogeneous thick paste.

\section{Experimental program}

\subsection{Materials}

In the present research, binary pastes were studied (fine materials + water). These pastes were composed of Portland cement CP V ARI, with specific gravity equal to $3,130 \mathrm{~kg} / \mathrm{m}^{3}$, and silica fume, with specific gravity equal to $2,180 \mathrm{~kg} / \mathrm{m}^{3}$. The particle size distribution of these materials is shown in Figure 3, where the results for the Portland cement were obtained by laser diffraction technique. The particle size distribution of the silica fume was provided by the manufacturer of the product. It is observed that the silica fume is much finer than the cement; more than $80 \%$ of its grains have a diameter finer than $1 \mu \mathrm{m}$. For the Portland cement, only about $10 \%$ of its grains have a diameter finer than $1 \mu \mathrm{m}$. The $D_{50}$ diameter was chosen as an input parameter to the analytical packing model calculations. This value is $6.24 \mu \mathrm{m}$ to the cement and $0.30 \mu \mathrm{m}$ to the silica fume. For paste production, a polycarboxylate-based superplasticizer was used, whose density is equal to $1,050 \mathrm{~kg} / \mathrm{m}^{3}$.

\subsection{Method}

First, the experimental method $[21,22]$ was used for the production of cement and silica fume pastes in order to determine the packing densities of each material individually. After that, the same method was applied for determining the packing density of the binary

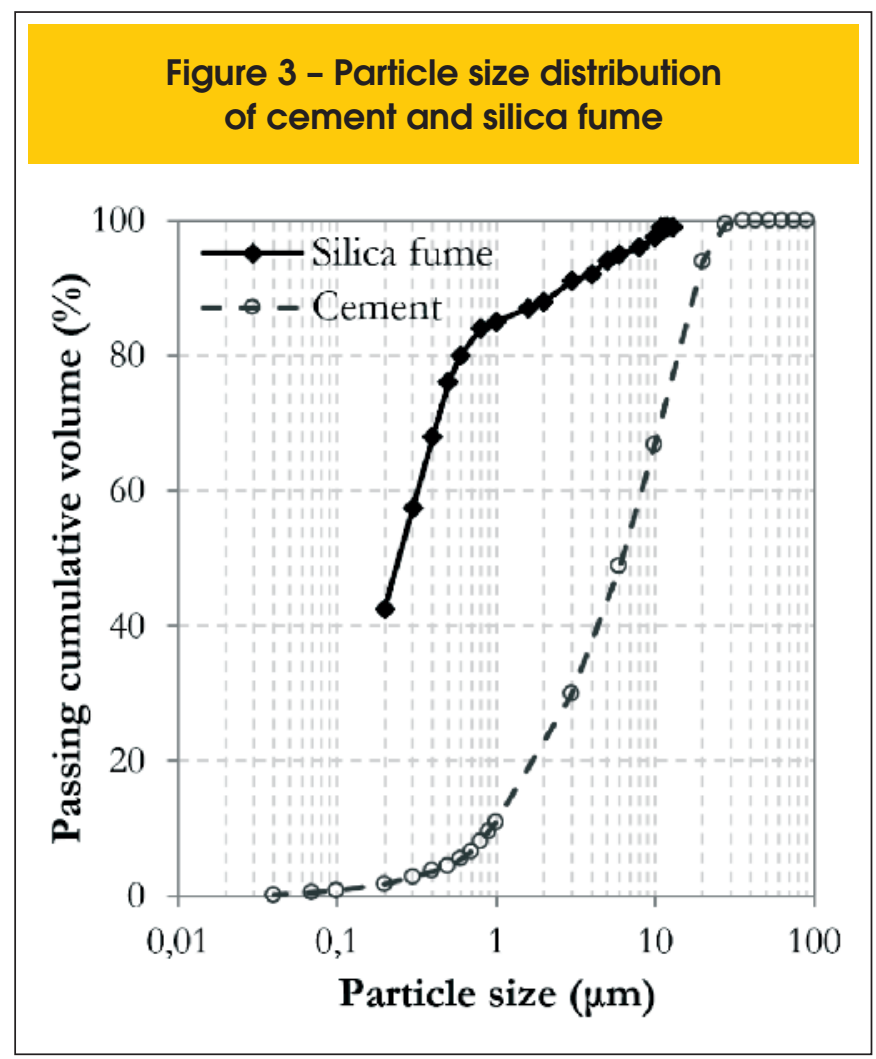


Table 1 - Mixture procedure of the materials, adapted from $(21,22)$

\begin{tabular}{|ccc|}
\hline Material & Mixing speed & Time \\
\hline $80 \%$ Water $+50 \%$ Binder $+100 \%$ Additive & Low & 3 minutes \\
\hline $12.5 \%$ Binder $+5 \%$ Water & Low & 45 seconds \\
\hline $12.5 \%$ Binder $+5 \%$ Water & Low & 45 seconds \\
\hline $12.5 \%$ Binder $+5 \%$ Water & Low & 45 seconds \\
\hline $12.5 \%$ Binder $+5 \%$ Water & Low & 45 seconds \\
\hline Total mixing time & & 6 minutes \\
\hline
\end{tabular}

mixture of cement and silica fume, being established a proportion of $85 \%$ cement and $15 \%$ silica fume by weight. These values were chosen based on the literature, which indicates the percentage of $15 \%$ of silica fume as the maximum value for the use together with cement $[3,12,13,14,15]$, as mentioned before.

The materials mix proceeding is shown in Table 1. It is based on the recommendation of the authors, proposers of the method. Minor changes have been made. First, $80 \%$ of all water, $50 \%$ of the binder (cement and/or silica fume) and $100 \%$ of the chemical admixture was added to a mixing bowl. The remaining material was divided into four equal portions, each portion being added every 45 seconds, always at the low speed. Thus, with $20 \%$ remaining water, each portion was composed with $5 \%$ of the total water. Similarly, with $50 \%$ of binder remaining, each portion was composed with $12.5 \%$ of the total binder. The difference between this method and the one proposed by the authors is the fact that the authors add $100 \%$ of the water at the beginning. This mixing procedure is proposed in order to reduce the time of mixture, since when approaching the condition of maximum solid concentration, the mixture becomes very dry and difficult to mix. By performing the mix procedure as indicated, the mix remains saturated with water for the longest possible time [21, 22].

After mixing, the paste was transferred into a cylindrical mould of $400 \mathrm{ml}$, which was filled in three layers. Each layer was compacted with 30 blows, applied with a rod. After that, the mass of the material needed to fill the mould was determined.

Several pastes were produced following the described procedure. The $\mathrm{w} / \mathrm{b}$ ratio was varied from 0.10 to 0.60 for the cement and from 0.50 to 0.90 for the silica fume. The range of variation was of 0.05 in both cases. For the binary mixture of cement and silica fume, the $\mathrm{w} / \mathrm{b}$ ratio was varied from 0.18 to 0.25 . It is important to notice that the $w / b$ ratios are expressed by weight; however, the experimental method considers the $\mathrm{w} / \mathrm{b}$ ratio by volume (as will be observed in the presentation of the results). The corresponding intervals, by volume, are equal to the variations from 0.31 to 1.86 for the cement, from 1.09 to 1.96 for the silica fume and from 0.66 to 0.91 for the binary mixture. The range of variation in the $w / b$ ratio is not the same in the three cases, because the amount of water needed to obtain the packing density of each material varies. For example, the silica fume has a higher water demand compared with the cement, due to its higher specific surface. Therefore, the $w / b$ ratios for the silica are also higher. The superplasticizer was used in $1 \%$ by binder weight.

After the experimental determination of the packing density of the cement, the silica fume and the binary mixture, the analytical model CPM [18] was used to determine the maximum packing density compositions between the two materials. For this verification, the amount of cement in the mixture was varied from 99 to $70 \%$, while the variation of the silica fume has been established from 1 to $30 \%$, so the percentages of the two materials used would complement each other, totalling $100 \%$. This range of values was chosen to contrast with the usual amounts of silica fume indicated in the literature, between 5 and $15 \%$. The theoretical and the experimental results were compared.

\section{Results and discussions}

The evolution of the voids ratio and the solid concentration of the produced pastes can be seen in Figure 4. The maximum solid concentration for each material is considered equal to the packing density of the particles in the wet condition. Thus, it is observed that the maximum solid concentration for the cement is equal to 0.614. On the other hand, the silica fume was the material that presented the lowest packing density, equal to 0.414 . The binary mixture of the two materials, in the proportion of $15 \%$ of silica fume and $85 \%$ of cement, by weight, resulted in an intermediate value of packing density, equal to 0.577 .

For the cement, the packing density of 0.614 corresponds to a voids ratio equal to 0.630 , this being the minimum voids ratio found. These values are found when the $\mathrm{w} / \mathrm{b}$ ratio is equal to 0.465 (by volume) or 0.15 (by weight). This indicates that when the w/b ratio is less than 0.465 , a homogeneous paste cannot be produced. As a result, the voids ratio increases and the solid concentration decreases, indicating that the amount of water is not enough. Similarly, when the $\mathrm{w} / \mathrm{b}$ ratio is higher than 0.465 , there is excess water between the particles, which causes dispersion, decreasing the solid concentration and increasing the voids ratio.

Regarding the silica fume, its packing density, equal to 0.414 , was lower than that found for the cement, with a voids ratio equal to 1.413. The high voids ratio agrees with the low packing density of the material. This is explained by the high fineness of the silica fume. Since its particles are finer and lighter than the cement particles, they are most prone to agglomeration. Thus, the agglomerated particles create open channels networks, where part of the water that should be used to promote fluidity of the mixture is imprisoned. For this reason, the silica fume presented a $w / b$ ratio much higher than the one presented by cement in order to reach the packing density, equal to 1.308 (by volume) and 0.60 
(by weight). Moreover, among the agglomerated silica fume particles there is also imprisoned air, which can explain the high voids ratio presented by this material. It is important to highlight that the amount of superplasticizer used was equal to $1 \%$ by binder weight, in all mixtures (the ones with cement and silica fume). As the silica fume has a higher specific surface area than the cement, the effect of this chemical admixture into the particles may have been impaired, as it may not have been enough admixture to cover all the silica fume particles (with greater area). This contributes to a higher agglomeration of silica fume particles, when compared with the cement.

Finally, the binary mixture of $85 \%$ cement and $15 \%$ silica fume, by weight, presented an intermediate packing density between those obtained for the cement and the silica fume, equal to 0.577 . The void ratio was equal to 0.722 . It can be observed that the binary mixture did not increase the particle packing density, as expected, probably because the silica fume did not fill the voids between cement particles satisfactorily. It is important to highlight that the amount of superplasticizer, equal to $1 \%$ by binder weight, may not have been enough to promote a complete dispersion of the silica fume particles, causing the formation of agglomerates. The same effect was observed in the pastes composed only by silica fume. This is justified by the much higher specific surface area of the silica fume, when compared with the cement. Moreover, these silica fume agglomerates may have sizes larger than the cement grains; thus, promoting the loosening effect over the particles instead of the filler effect.

In addition to the influence of the superplasticizer associated with the high specific surface area of the silica fume, there is also the effect of the $\mathrm{w} / \mathrm{b}$ ratio in the packing density of the binary mixture. As already mentioned, for the cement paste and the silica fume paste the $\mathrm{w} / \mathrm{b}$ ratios that provided maximum compactness were 0.465 and 1.308 (by volume) or 0.15 and 0.60 (by weight), respec- tively. However, for the binary mixture the $w / b$ ratio that promoted the packing density was 0.729 (by volume) or 0.20 (by weight). This is an intermediate value between the ones obtained for the cement and the silica fume pastes. First, the amount of cement in the mixture is greater than that of silica fume, which results in a w/b ratio nearest to the one obtained for the cement paste. Moreover, De Larrard [18] explains that for mixtures containing silica fume it is necessary to use a high content of superplasticizer to ensure better dispersion of the particles. This is because due to its fineness it tends to agglomerate in the form the author calls "grape-like clusters". Therefore, the packing density of the binary mixture was influenced by a combination of the following factors: low superplasticizer content, low $\mathrm{w} / \mathrm{b}$ ratio and high fineness of the silica fume.

For comparison purposes, four other studies were considered, developed by Wong and Kwan [16, 21, 22] and Miranda [25]. For cement packing density, Wong and Kwan [21, 22] used the same method described in this article, obtaining packing densities equal to 0.546 (cement without chemical admixture), 0.586 (cement with $0.6 \% 2^{\text {nd }}$ generation superplasticizer) and 0.622 (cement with $3 \%$ $3^{\text {rd }}$ generation superplasticizer). Another study, also carried out by Wong and Kwan [16], demonstrated that with 3\% polycarboxylatebased superplasticizer the cement packing density was equal to 0.631 . Miranda [25] obtained packing densities of 0.620 for the cement using the analytical method developed by De Larrard [18]. Therefore, it is possible to observe that these packing densities are very similar to those obtained in the present study, equal to 0.614 for the cement, with the addition of $1 \%$ polycarboxylate-based superplasticizer.

Miranda [25] obtained a packing density equal to 0.410 for the silica fume [25], which is very close to the result obtained in this study, of 0.414 . Finally, the binary mixture with $85 \%$ cement, $15 \%$ silica fume and $3 \% 3^{\text {rd }}$ generation polycarboxylate-based superplasticizer showed a packing density of 0.703 [21, 22] and 0.709 [16]. For

\section{Figure 4 - Voids ratio and solid concentration of the produced pastes}

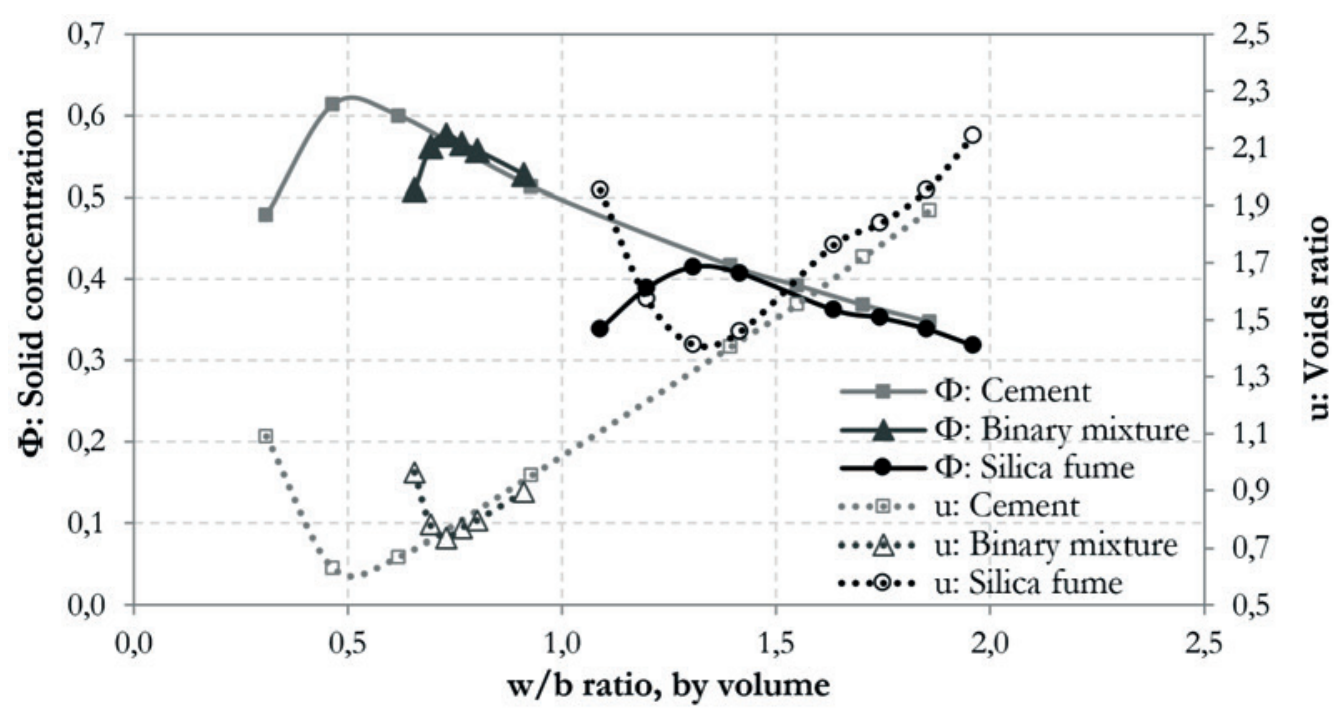




\section{Table 2 - Input parameters used for calculation using the CPM model}

\begin{tabular}{lcc}
\multicolumn{1}{c}{ Variables } & Cement & Silica fume \\
Volume fraction, $y_{i}(-)$ & Between 0.99 e 0.70 & Between 0.01 e 0.30 \\
\hline Packing density, $\beta_{i}(-)$ & 0.614 & 0.414 \\
\hline Particles size, $\alpha_{i}(\mu \mathrm{m})$ & 6.24 & 0.30 \\
\hline
\end{tabular}

the composition of $80 \%$ cement and $20 \%$ silica fume, a packing density of 0.644 was obtained [25]. These results are also close to the one obtained in this study, equal to 0.604 . The highest packing densities obtained for the binary mixture by the authors may respond to the higher amounts of superplasticizer used.

Thus, it can be observed that the packing density results obtained in the present study for both the cement and the silica fume, separately, as well as for the binary mixture, are very similar to those obtained by the authors $[16,21,22,25]$. This in view of the different types and percentages of the chemical admixtures used, as well as the different particle size distribution of the materials, silica fume and cement.

After the experimental determination of the packing density of each material, cement and silica fume, it becomes possible to apply the particle packing model, CPM. Table 2 summarizes the input parameters used for the application of this model. In this table, it can be observed that the content of silica fume varies from 1 to $30 \%$ by volume, since the maximum value recommended in

\section{Figure 5 - Variation of the particle packing density for the mixture of cement and silica fume according to the CPM}

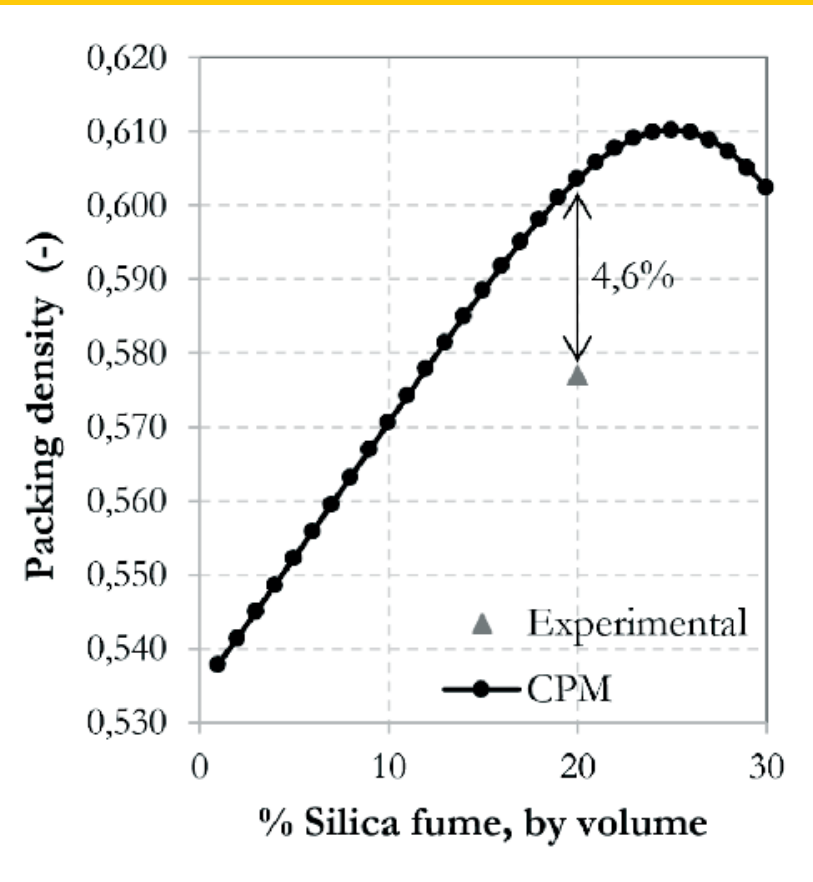

the literature, equal to $15 \%$ by weight, is in this range. The packing densities for each material were experimentally determined, according to the results previously presented in Figure 4 . The diameters adopted are equal to the diameter $D_{50}$ of the particle size distribution, according to Figure 3 . The compaction index $\mathrm{K}$ used was equal to 6.7, as recommended by De Larrard [18] for a smooth, thick paste.

The Figure 5 shows the packing density results obtained for the combinations of the materials studied. In this figure, it can be observed that the maximum packing density obtained by CPM model was equal to 0.610 for a silica fume content varying between 24 and $26 \%$ by volume. This corresponds to a silica fume percentage ranging from 18 to $20 \%$ by weight. These values, although close, are slightly higher than the recommended in the literature, which indicates a maximum silica fume content of $15 \%$ by weight. It is important to note that the particle packing model used, the CPM, does not consider in its equations the attractive forces between the fine particles. Consequently, it does not consider the agglomeration that the particles of cement and silica fume may suffer. This may justify the obtained results, since the CPM model recommends higher percentages of the silica fume in mixtures.

In this study, it was considered that the use of a superplasticizer would eliminate the agglomeration of the fine particles. However, there is no guarantee that this would effectively happen in practice. The superplasticizer works on reducing the agglomeration of the fine particles. However, the complete elimination of the phenomenon will depend on the effectiveness of the chemical admixture, the amount added to the mixture and the fineness of the binder. It is noteworthy that this study fixed the admixture content in $1 \%$ by binder weight, in order not to lose the comparison and to measure the packing density when the $w / b$ varies. An evaluation of the paste workability was not considered in this study. Moreover, the literature recommendations on the use of silica fume consider not only the increase in the packaging density that the material can provide, but also the specific surface area of the particles. The CPM model does not consider this last parameter in calculations.

The experimental packing density of the mixture produced with $80 \%$ cement and $20 \%$ silica fume by volume (corresponding to $85 \%$ cement and $15 \%$ silica fume by weight) was equal to 0.577 (Figure 4) and can be compared to the theoretical result, equal to 0.604 , in Figure 5. The difference between the results is equal to $4.6 \%$, which indicates a good approximation of the model. This difference is most likely a result of the inability of the CPM model in predicting the attraction effects between the fine particles. This feature of the model has been highlighted in the literature by other authors $[19,26]$, who recommend to consider the interaction effects between the fine particles in predicting the particle packing density. 


\section{Conclusions}

After performing the experimental campaign and applying the analytical model, the CPM, the following conclusions can be taken:

- The experimental method for determining the packing density in the wet condition, used for the production of the cement pastes, the silica fume pastes and the binary mixtures of this two materials proved to be effective and simple to determine the packing density of the fine materials;

- The packing density in the wet condition obtained for the materials studied is equal to 0.614 for the cement and 0.414 for the silica fume. The silica fume presented a lower value than the cement due to the fineness of its particles, which tend to agglomerate and to form open channels networks among the agglomerated silica fume particles. Furthermore, the silica fume has a higher specific surface area, which may have reduced the effect of the superplasticizer used in the dispersion of the particles;

- For the binary mixture ( $85 \%$ of cement and $15 \%$ of silica fume, by weight) a packing density equal to 0.577 was obtained, which is an intermediate value between the ones obtained for each material individually. Thus, in this work, the silica fume did not contribute for increasing the cement packing density. This probably happened due to the high fineness and specific surface area of the silica fume, which may have decreased the effect of the superplasticizer, fixed in $1 \%$ by binder weight. Moreover, the $\mathrm{w} / \mathrm{b}$ ratio used, lower than the one obtained for the silica fume paste, may have impaired the dispersion of the silica fume particles. This contributes to particle agglomeration and may cause the loosening of the cement particles, which decreases the packing density. This fact demonstrates the importance of considering not only the filler effect of the silica fume during the mix-design process, but also the effect of its high fineness and its water demand. Finally, the percentage of $15 \%$ may have been too high, so that the volume of silica fume added may have exceeded the volume of voids between the cement particles. It is noteworthy that $15 \%$ is the maximum percentage indicated by the literature, being used lower percentages in several occasions;

- According to the analytical packing model, the CPM, variations in the percentage of silica fume between 18 and $20 \%$ by weight would cause the maximum packing density of 0.610 . The experimental value of 0.577 for the mixture with $15 \%$ of silica fume is $4.6 \%$ lower than the value given by the model, equal to 0.604 . This is probably explained by the fact that the model does not consider the interaction between the fine particles, like the attraction forces of Van der Waals. Thus, the results demonstrate the need of considering these interactions between particles in the application of packing models to fine particles.

\section{Acknowledgements}

The authors would like to thank: the foundation CAPES (Coordenação de Aperfeiçoamento de Pessoal de Nível Superior) for the scholarships provided; the laboratory LAME/DCC (Laboratório de Materiais e Estruturas) of the UFPR (Universidade Federal do Paraná) for the availability of laboratories and equipment; and the companies Cimento Itambé and Tecnosil, for the supply of cement and silica fume used in this research. Lastly, the authors thank the postgrad student Alan C. Polucha, for his invaluable help in the laboratory work.

\section{References}

[1] AïTCIN, P.C. Concreto de alto desempenho, São Paulo: Pini, 2000.

[2] RAO, A.G. Investigations on the performance of silica fumeincorporated cement pastes and mortars. Cement and Concrete Research, v.33, 2003, p.1765-1770.

[3] MAZLOOM, M. RAMEZANIANPOUR, A.A. BROOKS, J.J. Effect of silica fume on mechanical properties of highstrength concrete. Cement and Concrete Composites, v.26, 2004, p.347-357.

[4] MEHTA, P.K. MONTEIRO, P.J.M. Concreto: microestrutura, propriedades e materiais, São Paulo: Pini, $2^{\mathrm{a}}$ ed, 2014.

[5] CHEN, J.J. FUNG, W.W.S. KWAN, A.K.H. Effects of CSF on strength, rheology and cohesiveness of cement paste. Construction and Building Materials, v.35, 2012, p.979-987.

[6] LI, L.G. KWAN, A.K.H. Packing density of concrete mix under dry and wet conditions. Powder Technology, v.253, 2014, p.514-521.

[7] LI, Y. KWAN, A.K.H. Ternary blending of cement with fly ash microsphere and condensed silica fume to improve the performance of mortar. Cement and Concrete Composites, v.49, 2014, p.26-35.

[8] NEVILLE, A.M. BROOKS, J.J. Tecnologia do concreto, Porto Alegre: Bookman, $2^{\mathrm{a}}$ ed, 2013.

[9] GOLDMAN, A. BENTUR, A. Properties of cementitious systems containing silica fume or nonreactive microfillers. Advanced Cement Based Materials, v.1, 1994, p.209-215.

[10] AMERICAN CONCRETE INSTITUTE. ACI 234 R-96 Guide for the use of silica fume in concrete, 2000.

[11] SILVA, F.G. LIBORIO, J.B.L. Durabilidade do concreto de alto desempenho com sílica de Fe-Si ou silício metálico em ambientes marinhos. In: Seminário e Workshop em Engenharia Oceânica, Rio Grande, 2004.

[12] GUTIERREZ, P.A. CANOVAS, M.F. High-performance concrete: requirements for constituent materials and mix proportioning. ACI Materials Journal, v.93, 1996.

[13] KHAN, M.I. Isoresponses for strength, permeability and porosity of high performance mortar. Building and Environment, v.38, 2003, p.1051-1056.

[14] WONG, H.S. RAZAK, H.A. Efficiency of calcined kaolin and silica fume as cement replacement material for strength performance. Cement and Concrete Research, v.35, 2005, p.696-702.

[15] WONGKEO, W. THONGSANITGARN, P. NGAMJARUROJANA, A. CHAIPANICH, A. Compressive strength and chloride resistance of self-compacting concrete containing high level fly ash and silica fume. Materials and Design, v.64, 2014, p.261-269.

[16] WONG, H.H.C. KWAN, A.K.H. Rheology of cement paste: role of excess water to solid surface area ratio. Journal of Materials in Civil Engineering, v.20, n.2, 2008, p. 189-197.

[17] LI, L.G. KWAN, A.K.H. Mortar design based on water film thickness. Construction and Building Materials, v.25, 2011, p.2381-2390. 
[18] DE LARRARD, F. Concrete mixture proportioning a scientific approach, London: E \& FN Spon, 1999.

[19] FENNIS, S.A.A.M. Design of ecological concrete by particle packing optimization, Delft, 2011, Tese (doutorado) - Technische Universiteit Delft, $256 \mathrm{p}$.

[20] OLIVEIRA, I. STUDART, A.R. PILEGGI, R.G. PANDOFELLI, V.C. Dispersão e empacotamento de partícula: princípios e aplicações em processamento cerâmico, São Paulo: Fazendo Arte, 2000, 224 p.

[21] WONG, H.H.C. KWAN, A.K.H. Packing density of cementitious materials: part 1 - measurement using a wet packing method. Materials and Structures, v.41, 2008, p.689-701.

[22] KWAN, A.K.H. WONG, H.H.C. Packing density of cementitious materials: part 2 - packing and flow of OPC + PFA + CSF. Materials and Structures, v.41, 2008, p.773-784.

[23] KLEIN, N.S. El rol físico del agua en mezclas de cemento Portland, Barcelona, 2012, Tese (doutorado) - Universitat Politècnica de Catalunya, $247 \mathrm{p}$.

[24] FLATT, R.J. Interparticle Forces and Superplasticizers in Cement Suspensions, Suíça, 1999, Tese (doutorado) - Escola Politécnica Federal de Lausanne, $330 \mathrm{p}$.

[25] MIRANDA, C. R. Pastas de cimento de alta compacidade para poços de petróleo - processo de formulação, propriedades reológicas, resistência mecânica e química, Rio de Janeiro, 2008, Tese (doutorado) - Instituto Militar de Engenharia, $291 \mathrm{p}$.

[26] FENNIS, S.A.A.M. WALRAVEN, J.C. DEN UIJL, J.A. Compaction-interaction packing model: regarding the effect of fillers in concrete mixture design. Materials and Structures, v.46, 2013, p.463-478. 